\author{
Michał SZCZYSZEK \\ Uniwersytet im. Adama Mickiewicza w Poznaniu \\ szczysze@amu.edu.pl \\ http://orcid.org/0000-0002-0253-7296
}

\title{
O POJĘCIACH HISTORIA I SPOLECZEŃSTWO W POLSKIM DYSKURSIE PARLAMENTARNYM (NA PODSTAWIE KORPUSU STENOGRAMÓW PARLAMENTARNYCH Z LAT 1918-2018)
}

\section{WSTĘP}

Rozumienie pojęć historia i społeczeństwo to jedno z trudniejszych zagadnień interdyscyplinarnych. Z tego względu interesujące wydaje się spojrzenie, jak te dwa pojęcia funkcjonują w polskim dyskursie parlamentarnym. W niniejszym przyczynku spróbujemy opisać zatem użycie leksemów historia, społeczeństwo - jako reprezentantów pojęć modelowanych semantycznie w dyskursie polskiego Sejmu i Senatu w latach 1918-2018. Spróbujemy zdefiniować (zdekodować), co w polskim parlamencie rozumiano poprzez użycie tych słów. Takie spojrzenie - od użycia wyrazu do próby rekonstrukcji jego pojęcia - jest możliwe dzięki pracom Zespołu Inżynierii Lingwistycznej Instytutu Podstaw Informatyki Polskiej Akademii Nauk nad językowym korpusem stenogramów polskiego parlamentu (Sejmu i Senatu) z lat 1918-2018. Prace te zaowocowały powstaniem Korpusu dyskursu parlamentarnego (dalej: KDP lub „Korpus...”; por. Ogrodniczuk 2018: 15-19; Ogrodniczuk 2012: 2219-2223), który jest nieustannie pomnażany o stenogramy z kolejnych debat parlamentu i z komisji parlamentarnych.

Głównym założeniem niniejszego tekstu jest to, że w dyskursie parlamentarnym znaczenia wyrazów w nim używanych podlegają „zakrzywieniu” semantycznemu, tj. pod wpływem „nacisku” tej sytuacji komunikacyjnej, znaczenia wyrazów podlegają określonym przekształceniom, obserwowalnym tylko $\mathrm{w}$ tym dyskursie. Podobnie rzecz dzieje się $\mathrm{z}$ fre- 
kwencją wyrazów. Zakładamy dalej, że oba współczynniki - znaczenie i frekwencja - „fluktuują" w zależności od okresu w historii polskiego parlamentaryzmu. W niniejszym przyczynku chcemy zatem zbadać, czy i jeśli tak, to jak zostały "zakrzywione” pod wpływem „nacisku” polskiego dyskursu parlamentarnego znaczenia i frekwencja dwóch leksemów przywołanych w tytule.

$\mathrm{Na}$ podstawie materiałów językowych zgromadzonych $\mathrm{w}$ korpusie zostały podjęte już wstępne językoznawcze prace analityczne ${ }^{1}$. Z tych powodów podam tu tylko najistotniejsze dane statystyczne (odsyłając Czytelnika do wskazanych w przypisie 1. opracowań). Łączna liczba segmentów (jednostek językowych, słowoform) zapisanych w „Korpusie...” wynosi $193727147^{2}$ (w tym wyekscerpowanych ze stenogramów Sejmu - 148951 586, a Senatu - 44775 561).

\section{NARZĘDZIA}

Na potrzeby analizy tak wielkiego korpusu konieczne było skorzystanie z narzędzi cyfrowych. Do opracowania materiału językowego na potrzeby tego artykułu wykorzystano bardzo operatywne narzędzie cyfrowe - Korpusomat (Kieraś, Kobyliński, Ogrodniczuk 2018: 21-27).

\footnotetext{
1 Niniejszy artykuł jest kolejnym w serii poświęconych językowi polskiego parlamentaryzmu. Dlatego też informacje wstępne są podobne bądź niekiedy identyczne z tymi zawartymi w artykułach: Szczyszek M., 2019, Emocje w parlamencie - parlament w emocjach: ujęcie statystyczne. O projekcie słownika polskiego parlamentaryzmu XX wieku (lata 1918-2018), „Prace Językoznawcze”, t. XXI, nr 3, s. 203-218; Szczyszek M., 2020, O miejskich (i nie tylko) rozrywkach w polskim dyskursie parlamentarnym (na podstawie korpusu stenogramów parlamentarnych z lat 1918-2018), [w:] Przestrzeń zróżnicowana językowo, kulturowo i społecznie. Miasto 8, red. M. Święcicka i M. Peplińska, Bydgoszcz: Wydawnictwo Uniwersytetu Kazimierza Wielkiego, s. 323-336; Szczyszek M., 2020, O „przemocy w mediach" w polskim dyskursie parlamentarnym (na podstawie korpusu stenogramów parlamentarnych z lat 1918-2018), [w:] Wspótczesne media. Przemoc w mediach, t. 2, pod red. I. Hofman i D. Kępy-Figury, Lublin: Wydawnictwo UMCS, s. 207-224 oraz w tekstach: Szczyszek M., O projekcie słownika polskiego parlamentaryzmu XX wieku (lata 1918-2018): etap wstępny - korpus parlamentarny (w druku); Szczyszek M., Dolecka P., Gumienna W., Piasecka M., Słów kilka o projekcie słownika polskiego parlamentaryzmu XX wieku (lata 1918-2018) (w druku); Szczyszek M., „O czym nie mówi się” w polskim parlamencie. Użycie leksemu tabu w parlamencie polskim (na podstawie korpusu stenogramów parlamentarnych z lat 1918-2018) (w druku).

2 Z rozmów ze współtwórcami „Korpusu...” - z informatykami IPI PAN - wynika, że „Korpus...” osiągnął - w wersji roboczej (nieopublikowanej jeszcze w momencie powstawania artykułu) - już wielkość rzędu 700 mln segmentów.
} 


\section{ANALIZY I METODY (METODOLOGIE)}

W dalszej części artykułu omówione zostaną jednostki leksykalne - historia, społeczeństwo - funkcjonujące w postaci wyrazów tekstowych w korpusie stenogramów. W ten sposób ukazanea zostanie zarówno złożoność i bogactwo materiału językowego pochodzącego z obrad polskiego parlamentu, jak i ogromna potencja badawczo-naukowa, która tkwi w przyjętych za podstawę materiałową niniejszych badań tekstach wystąpień sejmowych i senackich.

Do analiz językoznawczych wykorzystywane są utrwalone w polonistycznym językoznawstwie metody analiz leksykalnych (opisanych np. przez W. Miodunkę (1989) czy M. Bańkę (2001)) - głównie korzystam z semantycznej analizy składnikowej. W ramach rekonstrukcji profilowania badanego pojęcia w oczywisty sposób odwołuję się do prac J. Bartmińskiego (2006).

\section{ANALIZA WYBRANYCH JEDNOSTEK LEKSYKALNYCH FUNKCJONUJĄCYCH W KORPUSIE STENOGRAMÓW}

Poniżej zostaną przedstawione wyniki pracy Korpusomatu (na całym KPD, tj. liczącym ponad 193 mln jednostek), więc na materiale stenogramów polskiego parlamentu za lata 1918-2018. Wyniki przedstawione zostaną $\mathrm{w}$ postaci danych statystycznych dotyczących analizowanego szczegółowo na potrzeby tego tekstu leksemów wyekscerpowanych ze stenogramów, a także danych dotyczących semantyki tych leksemów i jej potencjalnych przemian obserwowalnych w stenogramach parlamentarnych badanego okresu. Badanie to przeprowadzono w przekrojach (ustalonych arbitralnie ze względu na możliwości techniczne Korpusomatu): każdy przekrój obejmował poszczególne dziesięciolecia XX wieku ( $\mathrm{tj}$. badano stenogramy pochodzące drugiego dziesięciolecia XX w., z lat: 20., 30., 40. 50., 60., 70., 80. i 90. XX wieku, z pierwszego i drugiego dziesięciolecia XXI w.). Na tej podstawie i na podstawie kontekstów odnalezionych przy użyciu Korpusomatu zostaną przeprowadzone analizy semantyczne dwóch leksemów: historia, społeczeństwo. 


\subsection{HISTORIA}

W słownikach wyraz ten jest definiowany następująco:

WSJP: '1. dzieje; ciąg wydarzeń z przeszłości, postrzegany jako proces, w wyniku którego ukształtował się obecny stan rzeczy; 2a. nauka, której przedmiotem są dzieje wspólnot ludzkich lub ich części albo procesy rozwoju czegoś; 2b. kierunek studiów zajmujący się historią jako nauką; 2c. wydział, administracyjnie wydzielona jednostka wyższej uczelni, w której wykładana jest historia jako kierunek; 2d. przedmiot w szkole poświęcony nauczaniu historii jako nauki; 2e. lekcja poświęcona nauczaniu historii jako przedmiotu szkolnego; 3. opowieść o jakimś zdarzeniu; 4. awantura, niezwykłe, emocjonujące wydarzenie'.

SJPD: '1. proces rozwoju życia społecznego lub przyrody; 2. nauka o dziejach, dzieło historyczne, utwór historyka; 3. wykład, lekcja historii, historia jako przedmiot nauczania; 4 . opowiadanie, powiastka osnute na jakimś zdarzeniu; 5. sprawa, zdarzenie, awantura, scena; 6. nadzwyczajność, niezwykłość'.

W korpusie stenogramów sejmowych leksem historia ma 30114 użyć w całym okresie obejmującym lata od 1918 do 2018.

W poszczególnych dziesięcioleciach frekwencja leksemu historia w dyskursie parlamentarnym wygląda następująco:

- drugie dziesięciolecie XX wieku (tj. lata 1918-1919): 13 użyć;

- lata 20. XX wieku: 155 użyć;

- lata 30. XX wieku: 509 użyć;

- lata 40. XX wieku: 309 użyć;

- lata 50. XX wieku: 603 użycia;

- lata 60. XX wieku: 494 użycia;

- lata 70. XX wieku: 347 użycia;

- lata 80. XX wieku: 1358 użyć;

- lata 90. XX wieku: 6793 użycia;

- pierwsze dziesięciolecie XXI wieku: 9796 użyć;

- drugie dziesięciolecie XXI wieku: 9736 użyć.

W odniesieniu do struktury semantycznej analizowanego leksemu można zauważyć - na podstawie analiz użycia tego leksemu w stenogramach parlamentarnych z całego badanego okresu - że leksem ten najczęściej występował w znaczeniu (znaczeniach) słownikowym (słownikowych) podawanym (podawanych) zarówno w SJPD, jak i w WSJP. Dokładniej: uaktywnia się głównie znaczenie opisane w WSJP jako: 1. 'dzieje; 
ciąg wydarzeń z przeszłości, postrzegany jako proces, w wyniku którego ukształtował się obecny stan rzeczy' (w SJPD odpowiednio: 1. 'proces rozwoju życia społecznego lub przyrody').

W badanym materiale dominuje neutralne użycie tego leksemu, choć zdarzają się konteksty pozytywne, wyrażające szacunek; nie odnotowano użyć o charakterze negatywnym.

Natomiast $\mathrm{w}$ poszczególnych wyodrębnionych na potrzeby niniejszego szkicu dziesięcioleciach semantyka - i ewentualne jej modyfikacje - kształtują się następująco:

\subsubsection{DRUGIE DZIESIĘCIOLECIE XX WIEKU (TJ. LATA 1918-1919)}

W tym okresie leksem ten przede wszystkim realizuje znaczenie słownikowe nr 1 - wskazane powyżej jako najczęstsze, główne: „Przeszłość narodu polskiego, historia dalszej i bliższej jego przeszłości, wreszcie historja [...]" (kontekst z 1919 r.); "Niezawodnie rozumny był ten człowiek, który powiedział, że historja jest mistrzynią narodów, chcemy czytać $\mathrm{w}$ niej, chcemy się $\mathrm{z}$ niej uczyć i chcemy ją mieć za taką. Jeśli wpatrzymy się $\mathrm{w}$ tę historię, jeśli posłuchamy sądu naszych historyków [...]" (kontekst z 1919 r. - tutaj ujawnia się także znaczenie opisane w WSJP jako: '2a. nauka, której przedmiotem są dzieje wspólnot ludzkich lub ich części albo procesy rozwoju czegoś', a w SJPD: '2. nauka o dziejach, dzieło historyczne, utwór historyka'). Jednakże pojawiają się też konteksty dokumentujące znaczenie opisane w WSJP jako: '4. awantura, niezwykłe, emocjonujące wydarzenie' (w SJPD analogicznie: '5. sprawa, zdarzenie, awantura, scena'): „Pozwalacie sobie na ordynarne historie, to się nazywa parlament!” (kontekst z 1919 r.); „Potem, jak zwykle, ta sprawa się rozrosła i po okolicznych miasteczkach zaczęła się akcja pogromowa - bicie żydów i grabież na tle Krzepickiej historii" (kontekst z 1919 r.).

\subsubsection{LATA 20. XX WIEKU}

$\mathrm{W}$ tym okresie leksem ten przede wszystkim realizuje znaczenie słownikowe nr 1 - wskazane powyżej jako najczęstsze, główne: „Ale, proszę Panów, za narodem ukraińskim, jak i za narodem polskim przemawia historia" (kontekst z 1923 r.); „Niema większego idealisty od chłopa polskiego i udowodnię to $\mathrm{p}$. Ministrowi historia. Udowodnię, proszę Panów, przykładami tego bohatera Wielocha $\mathrm{z}$ powiatu garwolińskiego, który wtenczas, kiedy armja Batorego odstępowała od twierdzy mo- 
skiewskiej Pskowa, choć był tylko ciurą obozowym [...] chwycił za łuczywo i podpalił twierdzę rosyjską" (kontekst z 1927 r. - tutaj ujawnia się także znaczenie opisane w WSJP jako: '3. opowieść o jakimś zdarzeniu', a w SJPD: '4. opowiadanie, powiastka osnute na jakimś zdarzeniu'). Jednakże pojawiają się też konteksty dokumentujące znaczenie opisane w WSJP jako :'4. awantura, niezwykłe, emocjonujące wydarzenie' (w SJPD analogicznie: '5. sprawa, zdarzenie, awantura, scena'): "Jeżeli Panowie myślą, że zgnębicie ten ferment, jaki w kraju jest, sądami doraźnemi, ogłoszeniem stanu wyjątkowego, albo podobnemi historiami" (kontekst z 1923 r.).

\subsubsection{LATA 30. XX WIEKU}

W tym okresie leksem ten przede wszystkim realizuje znaczenie słownikowe nr 1 - wskazane powyżej jako najczęstsze, główne: "Jest to bezpośrednie nawiązanie do tych momentów w naszej historii, które mówią o zmobilizowaniu wszystkich żywotnych sił narodowych w służbie Ojczyzny " (kontekst z 1938 r.); „Do wywodów p. referenta, który tak obszernie wyłuszczył historię i rozwój Kasy Oszczędności [...]" (kontekst z 1938 r.). Jednakże pojawiają się też konteksty dokumentujące znaczenie opisane w WSJP jako: ' $2 \mathrm{~d}$. przedmiot $\mathrm{w}$ szkole poświęcony nauczaniu historii jako nauki; 2e. lekcja poświęcona nauczaniu historii jako przedmiotu szkolnego' (w SJPD analogicznie: '3. wykład, lekcja historii, historia jako przedmiot nauczania'): „Chcę więc choć w kilku słowach poruszyć sprawę zapoznania z naszą historia już nie tylko młodzieży, lecz wszystkich." (kontekst z 1938 r.), a także - konteksty dokumentujące znaczenie opisane w WSJP jako: '4. awantura, niezwykłe, emocjonujące wydarzenie' (w SJPD analogicznie: '5. sprawa, zdarzenie, awantura, scena'): „Dlatego też nie stawiamy tego jako formę filantropii, jako piumdesiderium, żeby zmazać tę całą historię, pójść do domu i powiedzieć sobie, że co należało do nas, tośmy zrobili [...]" (kontekst z 1932 r.).

\subsubsection{LATA 40. XX WIEKU}

W tym okresie leksem ten przede wszystkim realizuje znaczenie słownikowe nr 1 - wskazane powyżej jako najczęstsze, główne: „W historii naszego bytu niepodległościowego przeżywaliśmy już raz okres tworzenia zrębów państwowości polskiej” (kontekst z 1947 r.); „PPS ma długą historię i dobrze to robi" (kontekst z 1947 r.). Jednakże pojawiają się też 
konteksty dokumentujące znaczenie opisane w WSJP jako: '2d. przedmiot $\mathrm{w}$ szkole poświęcony nauczaniu historii jako nauki; 2e. lekcja poświęcona nauczaniu historii jako przedmiotu szkolnego' (w SJPD analogicznie: '3. wykład, lekcja historii, historia jako przedmiot nauczania'): „Zdaje się, że panom z PSL potrzeba trochę nauki historii" (kontekst z 1947 r.).

\subsubsection{LATA 50. XX WIEKU}

$\mathrm{W}$ tym okresie leksem ten przede wszystkim realizuje znaczenie słownikowe nr 1 - wskazane powyżej jako najczęstsze, główne: „My właśnie, nasz obóz pragnie znieść wznoszoną »żelazną kurtynę", którą przestraszeni obrońcy starego świata chcą się zabezpieczyć przed postępem historii" (kontekst z 1957 r.); "Pamiętamy i ani na chwilę o tym zapomnieć nie wolno, że niepodległy byt naszego narodu i powstanie Polski Ludowej zawdzięczamy złamaniu przez Związek Radziecki najdzikszej postaci imperializmu, jaką dotychczas znała historia - złamania hitlerowskiego faszyzmu" (kontekst z 1957 r.). Jednakże pojawiają się też konteksty dokumentujące znaczenie opisane $\mathrm{w}$ WSJP jako: '3. opowieść o jakimś zdarzeniu' (a w SJPD: '4. opowiadanie, powiastka osnute na jakimś zdarzeniu'): „Na przykład powszechnie znane są $\mathrm{w}$ tym przemyśle historie ze skręcarką PL-9 [...]" (kontekst z 1957 r.), a także - konteksty dokumentujące znaczenie opisane w WSJP jako: '4. awantura, niezwykłe, emocjonujące wydarzenie' (w SJPD analogicznie: '5. sprawa, zdarzenie, awantura, scena'): „Rada Państwa nie wiedziała o tych historiach, które miały miejsce w Ministerstwie Bezpieczeństwa Publicznego, o tym naruszaniu praworządności?" (kontekst z 1956 r.).

\subsubsection{LATA 60. XX WIEKU}

W tym okresie leksem ten przede wszystkim realizuje znaczenie słownikowe nr 1 - wskazane powyżej jako najczęstsze, główne: „Tamten okres dziejów Polski, okres jej słabości [...] został całkowicie zamknięty, przeszedł do historii" (kontekst z 1967 r.); „Ale historia, choć zajmuje się przeszłością, jest także nauką o przyszłości, albo mówiąc ściślej - nauką dla przyszłości" (kontekst z 1968 r. - tutaj ujawnia się także znaczenie opisane w WSJP jako: '2a. nauka, której przedmiotem są dzieje wspólnot ludzkich lub ich części albo procesy rozwoju czegoś' (a w SJPD: '2. nauka o dziejach, dzieło historyczne, utwór historyka'). Jednakże pojawiają się 
też konteksty dokumentujące znaczenie opisane w WSJP jako: '2b. kierunek studiów zajmujący się historią jako nauką' (w SJPD analogicznie: '3. wykład, lekcja historii, historia jako przedmiot nauczania'): „Oto na przykład na wydziale humanistycznym stworzono kierunek o trójkierunkowej specjalizacji, a więc filologię polską jako przedmiot wiodący, historię i nauczanie początkowe" (kontekst z 1968 r.).

\subsubsection{LATA 70. XX WIEKU}

W tym okresie leksem ten przede wszystkim realizuje znaczenie słownikowe nr 1 - wskazane powyżej jako najczęstsze, główne: „Uruchomiono największą w naszej historii ilość nowych mocy energetycznych [...]" (kontekst z 1979 r.); "Jakże aktualne i symboliczne zarazem dla współczesnej epoki są te idee, przeplatające stałą nicią historię naszego kraju [...]" (kontekst z 1977 r.). Jednakże pojawiają się też konteksty dokumentujące znaczenie opisane w WSJP jako: '2a. nauka, której przedmiotem są dzieje wspólnot ludzkich lub ich części albo procesy rozwoju czegoś', a w SJPD: '2. nauka o dziejach, dzieło historyczne, utwór historyka'): „Także w zakresie nauk społecznych i humanistycznych ma Akademia bogaty dorobek w takich dyscyplinach, jak historia" (kontekst z 1970 r.).

\subsubsection{LATA 80. XX WIEKU}

W tym okresie leksem ten przede wszystkim realizuje znaczenie słownikowe nr 1 - wskazane powyżej jako najczęstsze, główne: „Doświadczenia historii najnowszej spowodowały [...]" (kontekst z 1989 r.); „Dlatego zwracamy się do was chłopi, których historia zna z patriotycznych postaw [...]" (kontekst z 1989 r.). Jednakże pojawiają się też konteksty dokumentujące znaczenie opisane w WSJP jako: '4. awantura, niezwykłe, emocjonujące wydarzenie' (w SJPD analogicznie: ‘5. sprawa, zdarzenie, awantura, scena'): „[...] Minister Kuroń nie może martwić się o zarobki piekarza w spółdzielni, bo to jest paranoja. Odchodzimy od systemu, w którym Minister i Rząd zajmowali się takimi historiami" (kontekst z 1989 r.).

\subsubsection{LATA 90. XX WIEKU}

W tym okresie leksem ten przede wszystkim realizuje znaczenie słownikowe nr 1 - wskazane powyżej jako najczęstsze, główne: „Do tego, jak ten urząd jest potrzebny, wracać już nie muszę, ale jak ta instytucja 
służy i służyła zabezpieczeniu w Polsce trwania demokracji, wskazuje jej historia” (kontekst z 1997 r.); „Długą historię ma sprawa odszkodowań dla osób represjonowanych przez komunistyczne władze radzieckie i polskie [...]" (kontekst z 1997 r.). Jednakże pojawiają się też konteksty dokumentujące znaczenie opisane w WSJP jako: '2a. nauka, której przedmiotem są dzieje wspólnot ludzkich lub ich części albo procesy rozwoju czegoś' (a w SJPD: '2. nauka o dziejach, dzieło historyczne, utwór historyka'): ,[...] to znaczy, że instytut powołany dla rozwoju historii, matematyki, filozofii, fizyki jest samodzielny $\mathrm{w}$ doborze swojej tematyki naukowej [...]" (kontekst z $1991 \mathrm{r}$.), a także - konteksty dokumentujące znaczenie opisane w WSJP jako: '3. opowieść o jakimś zdarzeniu' (w SJPD analogicznie: '4. opowiadanie, powiastka osnute na jakimś zdarzeniu'): „Gdyby dzisiaj ktoś chodził po szpitalu i opowiadał wszystkim pielęgniarkom nieprawdziwe historie na przykład na temat lekarza [...]" (kontekst z 1994 r.) oraz - konteksty dokumentujące znaczenie opisane w WSJP jako: '4. awantura, niezwykłe, emocjonujące wydarzenie' (w SJPD analogicznie: '5. sprawa, zdarzenie, awantura, scena'): „[...] aby zapobiec tego typu patologicznym historiom, jakie miały miejsce w 1989 i do połowy 1990 r." (kontekst z 1991 r.).

\subsubsection{PIERWSZE DZIESIĘCIOLECIE XXI WIEKU}

$\mathrm{W}$ tym okresie leksem ten przede wszystkim realizuje znaczenie słownikowe nr 1 - wskazane powyżej jako najczęstsze, główne: „Obywatele Ukrainy wybrali Was, abyście strzegli ich praw. Historia zna takie momenty, a zwłaszcza my, Polacy je znamy, kiedy ważą się losy narodu" (kontekst z 2004 r.); „,[...] są to projekty mające już długą historię zalegania w biurkach administracji Sejmu" (kontekst z 2005 r.). Jednakże pojawiają się też konteksty dokumentujące znaczenie opisane w WSJP jako: '2a. nauka, której przedmiotem są dzieje wspólnot ludzkich lub ich części albo procesy rozwoju czegoś' (w SJPD analogicznie: '2. nauka o dziejach, dzieło historyczne, utwór historyka'): „Otóż na poprzednim spotkaniu był tu przywołany przykład magistra historii" (kontekst z 2002 r.), a także - konteksty dokumentujące znaczenie opisane w WSJP jako: '4. awantura, niezwykłe, emocjonujące wydarzenie' (w SJPD analogicznie: '5. sprawa, zdarzenie, awantura, scena'): „[...] ze względu na hot dogi czy inne $h i-$ storie" (kontekst z 2004 r.) oraz - konteksty dokumentujące znaczenie opisane w WSJP jako: '3. opowieść o jakimś zdarzeniu' (w SJPD analogicznie: '4. opowiadanie, powiastka osnute na jakimś zdarzeniu'): „I za- 
pomina się o takich historiach, a o innych się pamięta, inne się nagłaśnia" (kontekst z 2006 r.).

\subsubsection{DRUGIE DZIESIĘCIOLECIE XXI WIEKU}

W tym okresie leksem ten przede wszystkim realizuje znaczenie słownikowe nr 1 - wskazane powyżej jako najczęstsze, główne: „[...] żeby przekazać państwu posłom całą historię kierowania Komisją do spraw Służb Specjalnych w poprzedniej kadencji [...]” (kontekst z 2015 r.); „Czy państwo interesujecie się tą właśnie historiq̨, a zarazem historia architektury polskiej?" (kontekst z 2010 r.). Jednakże pojawiają się też konteksty dokumentujące znaczenie opisane w WSJP jako: '4. awantura, niezwykłe, emocjonujące wydarzenie' (w SJPD analogicznie: '5. sprawa, zdarzenie, awantura, scena'): „Przygotowaliśmy raport o przemocy wobec starszych kobiet - dramatyczne historie" (kontekst z 2013 r.).

Z powyższego wynika, że $\mathrm{w}$ poszczególnych wyodrębnionych tu dziesięcioleciach dominuje - spośród 6 czy 8 znaczeń wyodrębnionych w przywołanych tu słownikach - znaczenie 1. - 'dzieje; ciąg wydarzeń z przeszłości, postrzegany jako proces, w wyniku którego ukształtował się obecny stan rzeczy' - za WSJP (w SJPD odpowiednio: '1. proces rozwoju życia społecznego lub przyrody') - jest główne, podstawowe, najczęściej aktualizowane.

Jednakże w poszczególnych dekadach uaktywniają się dodatkowe znaczenia. I tak:

- w drugim dziesięcioleciu XX wieku, w latach 20., 30., 50., 60. XX wie$\mathrm{ku}$ - pojawiają się jeszcze dodatkowo dwa znane słownikom znaczenia;

- w latach 40., 70., 80. XX wieku i w drugim dziesięcioleciu XXI wieku uaktywnia się jeszcze dodatkowo jedno znane słownikom znaczenie;

- w latach 90. XX wieku i w pierwszym dziesięcioleciu XXI wieku uaktywniają się jeszcze dodatkowo trzy znane słownikom znaczenia. Można zatem tu zrekonstruować sposób profilowania pojęcia historia, tak jak przebiegało ono w polskim parlamencie w XX i XX wieku. Pojęcie to definiuje się zatem przede wszystkim jako 'dzieje, proces rozwoju (np. społeczeństwa)'. Dodatkowym elementem semantycznym (w całym badanym okresie - z wyjątkiem lat 60., 70. XX wieku) są tu zazwyczaj: 'opowieść o czymś (o jakimś zdarzeniu)', a także - 'samo zdarzenie, awantura, sprawa'; ponadto (w latach 30., 40., 50. 60. XX wieku) - 'nauka hi- 
storii, nauczanie historii', a także - 'historia jako nauka' (w latach 60., 70., 90. XX wieku oraz w pierwszym dziesięcioleciu XXI wieku).

Dodatkową informacją świadczącą pośrednio o istotności tego pojęcia używanego w polskim dyskursie parlamentarnym jest jego frekwencja. W wypadku analizowanego tu leksemu przez większą cześć badanego okresu, tj. od lat 30. do lat 70. XX wieku, frekwencja była poniżej 1000 użyć $\mathrm{w}$ wyodrębnionej tu jednostce czasu (dziesięcioleciu), a maksymalnie nieco ponad 600 użyć na dziesięciolecie. Frekwencja ta wzrasta do powyżej 1300 użyć w latach 80. XX wieku, aby w latach 90. XX w. i w dwudziestoleciu XXI osiągnąć nawet poziom bliski 10 tys. użyć. Świadczy to dobitnie o wzroście zainteresowania historia - w tych głównych znaczeniach tego wyrazu, głównych "profilowaniach" wskazanych powyżej w ostatnich 30 latach, tj. na przełomie XX i XXI wieku.

Zatem „profilowanie” pojęcia historia, jego rozumienie w polskim dyskursie parlamentarnym jest - w różnych okresach - zazwyczaj nieco węższe niż w języku ogólnopolskim i ogranicza się przede wszystkim do znaczenia głównego; zdarza się, że w dyskursie parlamentarnym uaktywnia się któreś $\mathrm{z}$ pozostałych znaczeń wyodrębnianych $\mathrm{w}$ przywołanych tu słownikach, a jest - jak się wydaje w tym wypadku - uzależnione od momentu (nomen omen) w historii Polski, co pokazują powyższe analizy. Niemniej, generalnie wszystkie wyodrębniane w słownikach znaczenia uaktywniają się $\mathrm{w}$ polskim dyskursie parlamentarnym, choć właśnie $\mathrm{z}$ różną intensywnością w poszczególnych dziesięcioleciach.

\subsection{SPOŁECZEŃSTWO}

W słownikach wyraz ten jest definiowany następująco:

WSJP: '1. ogół ludzi mieszkających w jakimś kraju lub regionie, pozostających we wzajemnych stosunkach, wynikających z panujących tam warunków życia i gospodarowania; 2. ogół owadów zamieszkujących wspólne gniazdo, zorganizowanych $\mathrm{w}$ określone grupy ze względu na swoją budowę i rodzaj wykonywanej pracy'.

SJPD: '1. ogół ludzi pozostających we wzajemnych stosunkach, wynikających $\mathrm{z}$ ich udziału w procesach produkcyjnych i w życiu kulturalnym; ogół obywateli danego kraju, okręgu, miasta itp.; 2. ludzie poszczególnych środowisk zawodowych, społecznych; klasa społeczna; środowisko; 3a. dawne: towarzystwo, kompania, obcowanie, przebywanie z kim; 3b. wspólność, wspólnota'. 
W korpusie stenogramów sejmowych leksem społeczeństwo ma 93369 użyć w całym okresie obejmującym lata od 1918 do 2018.

W poszczególnych dziesięcioleciach frekwencja leksemu społeczeństwo w dyskursie parlamentarnym wygląda następująco:

- drugie dziesięciolecie XX wieku (tj. lata 1918-1919): 1259 użyć;

- lata 20. XX wieku: 7394 użycia;

- lata 30. XX wieku: 8049 użyć;

- lata 40. XX wieku: 915 użyć;

- lata 50. XX wieku: 2918 użyć;

- lata 60. XX wieku: 3092 użycia;

- lata 70. XX wieku: 3615 użyć;

- lata 80. XX wieku: 9364 użycia;

- lata 90. XX wieku: 25090 użyć;

- pierwsze dziesięciolecie XXI wieku: 21642 użycia;

- drugie dziesięciolecie XXI wieku: 10029 użyć.

W odniesieniu do struktury semantycznej omawianego leksemu można zauważyć - na podstawie analiz użycia tego leksemu w stenogramach parlamentarnych z całego badanego okresu - że leksem ten najczęściej, głównie występował w znaczeniu (znaczeniach) słownikowym (słownikowych) podawanym (podawanych) zarówno w SJPD, jak i w WSJP. Dokładniej: uaktywnia się głównie znaczenie opisane w WSJP jako: '1. 'ogół ludzi mieszkających w jakimś kraju lub regionie, pozostających we wzajemnych stosunkach, wynikających z panujących tam warunków życia i gospodarowania' (w SJPD odpowiednio: '1. ogół ludzi pozostających we wzajemnych stosunkach, wynikających z ich udziału w procesach produkcyjnych i w życiu kulturalnym; ogół obywateli danego kraju, okręgu, miasta itp.').

W badanym materiale dominuje neutralne użycie tego leksemu, choć zdarzają się konteksty pozytywne, z szacunkiem; nie odnotowano użyć o charakterze negatywnym.

Natomiast $\mathrm{w}$ poszczególnych wyodrębnionych na potrzeby niniejszego szkicu dziesięcioleciach semantyka - i ewentualne jej modyfikacje - kształtują się następująco:

\subsubsection{DRUGIE DZIESIĘCIOLECIE XX WIEKU (TJ. LATA 1918-1919)}

W tym okresie leksem ten przede wszystkim realizuje znaczenie słownikowe nr 1 - wskazane powyżej jako najczęstsze, główne: „Dlatego, że wiedział, że spotka się z oporem człowieka, szanującego swój urząd 
i swoje stanowisko w społeczeństwie" (kontekst z 1919 r.); ,[...] garstka opanowała władzę, nie pozwalając społeczeństwu się rozwijać [...]" (kontekst z 1919 r.). Niekiedy pojawiają się też konteksty dokumentujące znaczenie opisane tylko w SJPD jako bardzo szczegółowe wyodrębnienie, rozróżnienie: '2. ludzie poszczególnych środowisk zawodowych, społecznych; klasa społeczna; środowisko': „Dzisiejsze czasy, przełomowe poprostu wymagają tego i nasuwają potrzebę wyłonienia ze społeczeństwa jakiegoś geniusza społeczno pedagogicznego [...]" (kontekst z 1919 r.), a także znaczenie opisane tylko w SJPD jako dawne: '3b. wspólność, wspólnota': „,[...] Rząd Polski i władze polskie [...] powinny tylko ułatwiać działalność, oraz pracę społeczeństw miejscowych [...]" (kontekst z 1919 r.).

\subsubsection{LATA 20. XX WIEKU}

$\mathrm{W}$ tym okresie leksem ten przede wszystkim realizuje znaczenie słownikowe nr 1 - wskazane powyżej jako najczęstsze, główne: „Jest to sprawa akcji ratowniczej, którą podejmuje społeczeństwo względem więźniów [...]” (kontekst z 1924 r.); „Sprawiedliwość, która powinna rządzić Rządem, Państwem i całem społeczeństwem ku zadowoleniu wszystkich czynników [...]" (kontekst z 1924 r.). Niekiedy pojawiają się też konteksty dokumentujące znaczenie opisane tylko w SJPD jako bardzo szczegółowe wyodrębnienie, rozróżnienie: '2. ludzie poszczególnych środowisk zawodowych, społecznych; klasa społeczna; środowisko'): „[...] dlatego na stanowiska sędziów trzeba dobierać ludzi najlepszych, że się tak wyrażę, elitę prawniczą społeczeństwa" (kontekst z 1924 r.), a także znaczenie opisane tylko w SJPD jako dawne: '3b. wspólność, wspólnota': „,[...] nie da się zaprzeczyć, że zeznanie, jako podstawa wymiaru podatkowego, funkcjonuje sprawnie tylko w społeczeństwach, gospodarczo stojących na najwyższej wyżynie" (kontekst z 1925 r.).

\subsubsection{LATA 30. XX WIEKU}

$\mathrm{W}$ tym okresie leksem ten przede wszystkim realizuje znaczenie słownikowe nr 1 - wskazane powyżej jako najczęstsze, główne: „[...] mielibyśmy do czynienia z pewnym programem przedstawionym całemu spoteczeństwu zanim jeszcze wogóle Sejm był zebrany" (kontekst z 1930 r.); „Bez względu na to, że myśmy protestowali z tej trybuny przed społeczeństwem polskiem i przed całym światem [...]" (kontekst z 1930 r.). Niekiedy pojawiają się też konteksty dokumentujące znaczenie opisane tylko w SJPD jako bardzo szczegółowe wyodrębnienie, rozróżnienie: '2. ludzie 
poszczególnych środowisk zawodowych, społecznych; klasa społeczna; środowisko'): „W uznaniu tych Jego zasług społeczeństwo miejscowe wybiera go do szeregu organizacji społecznych [...]" (kontekst z 1932 r.).

\subsubsection{LATA 40. XX WIEKU}

W tym okresie leksem ten przede wszystkim realizuje znaczenie słownikowe nr 1 - wskazane powyżej jako najczęstsze, główne: „Projekt nasz nie uwzględnia przemian, które dokonały się $\mathrm{w}$ społeczeństwie polskim i chciałoby społeczeństwo cofnąć do stanu z 1921 r." (kontekst z 1947 r.); „Rząd ostatecznie i bez reszty wraz z całym społeczeństwem zlikwiduje wszelką działalność sabotażową i dywersyjną [...]" (kontekst z 1948 r.). Niekiedy pojawiają się też konteksty dokumentujące znaczenie opisane tylko w SJPD jako dawne: '3b. wspólność, wspólnota': „[...] ustawa o ustroju i zakresie działania najwyższych organów Rzeczypospolitej Polskiej spotka się z uznaniem całego społeczeństwa [...]" (kontekst z 1947 r.).

\subsubsection{LATA 50. XX WIEKU}

W tym okresie leksem ten przede wszystkim realizuje znaczenie słownikowe nr 1 - wskazane powyżej jako najczęstsze, główne: „Przytoczona wyżej analiza przebiegu wyborów wskazuje, że społeczeństwo obdarzyło nas wielkim zaufaniem [...]" (kontekst z 1957 r.); ,,[...] prasa winna pomóc społeczeństwu w odróżnianiu treści tego, co jest restauracją od tego, co jest postępem" (kontekst z 1956 r.). Niekiedy pojawiają się też konteksty dokumentujące znaczenie opisane tylko w SJPD jako bardzo szczegółowe wyodrębnienie, rozróżnienie: '2. ludzie poszczególnych środowisk zawodowych, społecznych; klasa społeczna; środowisko'): „W ten sposób rady robotnicze przyczynią się $\mathrm{w}$ skuteczniejszy sposób do uzyskania funduszu zakładowego przez załogi, a jednocześnie do wygospodarowania środków dla całego społeczeństwa" (kontekst z 1957 r.).

\subsubsection{LATA 60. XX WIEKU}

W tym okresie leksem ten przede wszystkim realizuje znaczenie słownikowe nr 1 - wskazane powyżej jako najczęstsze, główne: „Niedostateczna ich podaż lub niska jakość są w odczuciu społeczeństwa hamulcem wzrostu stopy życiowej, powodują, że rzeczywiste warunki bytu ludności kształtują się poniżej możliwości [...]” (kontekst z 1967 r.); „Od instytucji odpowiedzialnej za całokształt rozwoju nauki i techniki można by też w sposób uzasadniony oczekiwać uświadomienia społeczeństwu [...]" 
(kontekst z 1968 r.). Niekiedy pojawiają się też konteksty dokumentujące znaczenie opisane tylko w SJPD jako bardzo szczegółowe wyodrębnienie, rozróżnienie: '2. ludzie poszczególnych środowisk zawodowych, społecznych; klasa społeczna; środowisko'): „Jest to dziś człowiek bezpośrednio związany z życiem, z pracą, człowiek kierujący pracą tego społeczeństwa jawnie, codziennie, w powiązaniu z tym społeczeństwem [...]" (kontekst z 1968 r.).

\subsubsection{LATA 70. XX WIEKU}

W tym okresie leksem ten przede wszystkim realizuje znaczenie słownikowe nr 1 - wskazane powyżej jako najczęstsze, główne: „Osiągnięty stan funkcjonowania rynku wymaga na wielu odcinkach bardziej odczuwalnego postępu, stosownie do potrzeb i wymagań społeczeństwa" (kontekst z 1979 r.); "Powstrzymano też zbyt silnie rosnące płace w najwyższych przedziałach płacowych, co nieraz budziło zastrzeżenia w społeczeństwie" (kontekst z 1979 r.). Niekiedy pojawiają się też konteksty dokumentujące znaczenie opisane tylko w SJPD jako dawne: '3b. wspólność, wspólnota': „Dla umocnienia jedności wspólnoty socjalistycznej ważne znaczenie ma pogłębianie związków ideologicznych, rosnąca współpraca organizacji politycznych, społecznych i kulturalnych, rozszerzające się kontakty między społeczeństwami" (kontekst z 1972 r.).

\subsubsection{LATA 80. XX WIEKU}

W tym okresie leksem ten przede wszystkim realizuje znaczenie słownikowe nr 1 - wskazane powyżej jako najczęstsze, główne: „Rząd chce utrwalenia tradycyjnego w naszym społeczeństwie szacunku do obowiązku żołnierskiego" (kontekst z 1989 r.); "Odrzucamy filozofię polityczną zakładającą, że reformy gospodarcze można wprowadzić wbrew społeczeństwu, ponad jego głowami [...]" (kontekst z 1989 r.). Niekiedy pojawiają się też konteksty dokumentujące znaczenie opisane tylko w SJPD jako dawne: '3b. wspólność, wspólnota': „Pojmuję je przede wszystkim jako wielkie, zbiorowe wołanie społeczeństwa o podmiotowość [...]" (kontekst z 1989 r.).

\subsubsection{LATA 90. XX WIEKU}

W tym okresie leksem ten przede wszystkim realizuje znaczenie słownikowe nr 1 - wskazane powyżej jako najczęstsze, główne: „Nie powodujmy dalszych napięć społecznych w już i tak rozgoryczonym społeczeństwie" (kontekst z 1991 r.). Niekiedy pojawiają się też konteksty doku- 
mentujące znaczenie opisane tylko w SJPD jako bardzo szczegółowe wyodrębnienie, rozróżnienie: '2. ludzie poszczególnych środowisk zawodowych, społecznych; klasa społeczna; środowisko': „Przez swe nadmierne zbiurokratyzowanie i podporządkowanie centralistycznemu systemowi państwa nie przystają do zmienionego modelu naszej gospodarki, nie odpowiadają bowiem gospodarce rynkowej, nie uwzględniają też $\mathrm{w}$ pełni samorządności lokalnych społeczeństw [...]" (kontekst z 1992 r.), a także znaczenie opisane tylko w SJPD jako dawne: '3b. wspólność, wspólnota': „To jest problem niedostatecznej aktywności czy sterowania ze strony państwa, ale jest to równocześnie jeden z elementów naszej słabości jako kraju i społeczeństwa” (kontekst z 1991 r.); „Przyjmijmy taką formułę, tylko że jest to formuła niezwykle ryzykowna, a ryzykowna jest dlatego, że jakoś naszym sąsiadom, państwom, społeczeństwom europejskim nie udało się zbudować [...]" (kontekst z 1990 r.).

\subsubsection{PIERWSZE DZIESIĘCIOLECIE XXI WIEKU}

W tym okresie leksem ten przede wszystkim realizuje znaczenie słownikowe nr 1 - wskazane powyżej jako najczęstsze, główne: „Bo społeczeństwo ubożeje, dużo bezrobotnych, ludzie nie mają z czego płacić" (kontekst z 2002 r.); ,Jakie rodzaje przedsięwzięć [...] muszą być konsultowane ze społeczeństwem na mocy dzisiaj proponowanej ustawy?" (kontekst z 2000 r.). Niekiedy pojawiają się też konteksty dokumentujące znaczenie opisane tylko w SJPD jako bardzo szczegółowe wyodrębnienie, rozróżnienie: '2. ludzie poszczególnych środowisk zawodowych, społecznych; klasa społeczna; środowisko'): „Ponadto jak ocenić pojawienie się drugiej formy pomocy socjalnej państwa tylko dla pewnej grupy w społeczeństwie, czyli dla uczniów szkół powszechnych?" (kontekst z 2004 r.), a także znaczenie opisane tylko w SJPD jako dawne: '3b. wspólność, wspólnota': „To [...] chciałbym zainspirować rząd do tworzenia prawa sprzyjającego rodzinom wielopokoleniowym, sprzyjającego budowaniu postaw opiekuńczych, sprzyjającego budowaniu odpowiedzialnego społeczeństwa obywatelskiego" (kontekst z 2002 r.); "Zamiast budować społeczeństwa narodowe [...] budujemy jakąś czapę, nazywając to społeczeństwami narodowymi" (kontekst z 2006 r.).

\subsubsection{DRUGIE DZIESIĘCIOLECIE XXI WIEKU}

$\mathrm{W}$ tym okresie leksem ten przede wszystkim realizuje znaczenie słownikowe nr 1 - wskazane powyżej jako najczęstsze, główne: „[...] obo- 
wiązek operatorów obiektów energetyki jądrowej w zakresie informowania społeczeństwa o działalności obiektów energetyki jądrowej" (kontekst z 2011 r.); „Dlaczego premier Donald Tusk zgłasza propozycję referendum przy braku podstawowej wiedzy w społeczeństwie na temat energetyki jądrowej [...]" (kontekst z 2011 r.). Niekiedy pojawiają się też konteksty dokumentujące znaczenie opisane tylko w SJPD jako bardzo szczegółowe wyodrębnienie, rozróżnienie: '2. ludzie poszczególnych środowisk zawodowych, społecznych; klasa społeczna; środowisko': „Pana wyczyny na terenach wiejskich to doprawdy współczesna, powolna i przemyślana eksterminacja społeczeństw wiejskich [...]" (kontekst z 2013 r.), a także znaczenie opisane tylko w SJPD jako dawne: '3b. wspólność, wspólnota': „Ponieważ uważam, że powinna być przeprowadzona dyskusja na temat zapewnienia społeczeństwu poczucia bezpieczeństwa [...]" (kontekst z 2011 r.); „Niezbędne będzie zintensyfikowanie działań mających na celu umacnianie kontaktów między społeczeństwami naszych krajów, a także promocja i upowszechnianie kultury oraz historii Europu Środkowej [...]" (kontekst z 2012 r.).

Z powyższego wynika, że w poszczególnych wyodrębnionych tu dziesięcioleciach dominuje - spośród 2 czy 3 znaczeń wyodrębnionych w przywołanych tu słownikach - znaczenie 1.: 'ogół ludzi mieszkających w jakimś kraju lub regionie, pozostających we wzajemnych stosunkach, wynikających z panujących tam warunków życia i gospodarowania' za WSJP (w SJPD odpowiednio: '1. ogół ludzi pozostających we wzajemnych stosunkach, wynikających $\mathrm{z}$ ich udziału w procesach produkcyjnych i w życiu kulturalnym; ogół obywateli danego kraju, okręgu, miasta itp.') jest główne, podstawowe, najczęściej aktualizowane.

Jednakże w poszczególnych dekadach uaktywniają się dodatkowe znaczenia. I tak:

- w drugim dziesięcioleciu XX wieku, w latach 20. i 90. XX wieku oraz w pierwszym i drugim dziesięcioleciu XXI wieku uaktywniają się jeszcze dodatkowo dwa znane słownikom znaczenia;

- w latach 30., 40., 50., 60., 70. i 80. XX wieku - uaktywnia się jeszcze dodatkowo jedno znane słownikom znaczenie.

Można zatem tu zrekonstruować sposób profilowania pojęcia społeczeństwo, uwidaczniający się $\mathrm{w}$ polskim parlamencie $\mathrm{w}$ XX i XX wieku. Pojęcie to profiluje się zatem przede wszystkim jako 'ogół ludzi pozostających we wzajemnych stosunkach'. Dodatkowym elementem semantycz- 
nym (semy obecne w drugim dziesięcioleciu XX wieku oraz w latach 20., 30., 50., 60., 90. XX wieku, a także w pierwszym i w drugim dziesięcioleciu XXI wieku) jest tu 'grupa środowiskowa, zawodowa', a także - uznane przez SJPD - za dawne 'wspólnota' (obecne w drugim dziesięcioleciu XX wieku oraz w latach 20., 40., 70., 80., 90. XX wieku, a także w pierwszym i w drugim dziesięcioleciu XXI wieku; nota bene - w latach 90. XX wieku oraz $\mathrm{w}$ pierwszym i w drugim dziesięcioleciu XXI wieku to znaczenie staje się coraz częstsze, coraz mocniejsze).

Dodatkową informacją świadczącą pośrednio o istotności tego pojęcia używanego w polskim dyskursie parlamentarnym jest jego frekwencja. W wypadku omawianego tu leksemu przez większą część analizowanego okresu, tj. od lat 20. do lat 70. XX wieku, frekwencja była bardzo wysoka, liczona kilku tysiącami wystąpień w każdym dziesięcioleciu (z wyjątkiem lat 40. XX wieku, ale jest to rezultat braku posiedzeń polskiego parlamentu w trakcie II wojny światowej). Frekwencja ta w latach 80. wieku wzrasta do blisko 10 tys. użyć (podobnie w czasie tuż przedwojennym - w latach 30. XX wieku), aby w latach 90. XX wieku i w pierwszym dziesięcioleciu $X X$ wieku osiągnąć poziom ponad 20 tys. wystąpień. Natomiast w drugim dziesięcioleciu XXI wieku frekwencja spada do poziomu nieco ponad 10 tys. użyć (jednakże - drugie dziesięciolecie jeszcze trwa i liczba ta może wzrosnąć). Świadczy to dobitnie o bardzo dużym zainteresowaniu pojęciem wyrażanym leksemem społeczeństwo $\mathrm{w}$ polskim dyskursie parlamentarnym, o wyrazistym wzroście zainteresowania tym pojęciem na przełomie XX i XXI wieku - w tych głównych znaczeniach tego wyrazu, głównych „profilowaniach” wskazanych powyżej.

Zatem "profilowanie" pojęcia społeczeństwo, jego rozumienie w polskim dyskursie parlamentarnym jest generalnie nieco węższe niż w języku ogólnopolskim i ogranicza się przede wszystkim do znaczenia głównego; zdarza się, że w dyskursie parlamentarnym uaktywnia się któreś z pozostałych (szczegółowych) znaczeń wyodrębnianych w przywołanych tu słownikach, co pokazują powyższe analizy. Niemniej, generalnie wszystkie wyodrębniane w słownikach znaczenia uaktywniają się w polskim dyskursie parlamentarnym, choć właśnie z różną intensywnością w poszczególnych dziesięcioleciach. 


\section{PODSUMOWANIE}

Powyższe informacje dotyczące stenogramów parlamentu polskiego za lata 1918-2018 nie stanowią - bo stanowić nie mogą w tym krótkim przyczynku - pełnej palety danych i ich interpretacji. Jest to raczej niewielka próbka możliwości tkwiących zarówno w samym materiale językowym, jak i narzędziach cyfrowych, za pomocą których przeprowadzone zostały te wstępne analizy zaprezentowane $\mathrm{w}$ niniejszym tekście. Jednakże już ta próbka badań pokazuje - w moim przekonaniu - przeogromny potencjał badawczy tkwiący w samym materiale językowym, który - jako niemały korpus danych - może być z powodzeniem przeszukiwany i opracowywany m.in. za pomocą tych narzędzi z zakresu humanistyki cyfrowej (jak i innych narzędzi cyfrowych).

Istotnym składnikiem niniejszego przyczynku było zaprezentowanie szczegółowych analiz semantycznych dwóch wybranych, ważnych leksemów pojawiających się w stenogramach na przestrzeni badanego tu okresu - a więc potencji badawczej tkwiącej de facto w korpusie polskiego parlamentaryzmu. Dzięki danym z korpusu widać wyraźnie, czy i jak zmienia się pod względem użycia w tym dyskursie znaczenie leksemu, a zatem - jakiej kategoryzacji językowej poddawane są pojęcia (tu: te dwa analizowane) w dyskursie parlamentarnym (o kategoryzacji - w myśl prac powstających w nurcie kognitywizmu, dotyczących językowego obrazu świata, zob. np. Bartmiński 2006).

$\mathrm{Na}$ podstawie analizowanych w niniejszym przyczynku dwóch przykładów można dostrzec, jak zmienia się znaczenie tych dwu leksemów, aktualizowane $\mathrm{w}$ dyskursie parlamentarnym, jak fluktuuje ich profilowanie, czy jeszcze inaczej - jak faluje profilowanie tych pojęć, kategoryzowanie zjawisk, do których się one odnoszą w zależności od okresu, w którym leksemy historia i społeczeństwo się pojawiają. W odniesieniu do leksemu historia mamy wyraźny "główny nurt znaczeniowy" - uaktualniane zawsze, $\mathrm{w}$ całym badanym okresie $\mathrm{w}$ dyskursie parlamentarnym główne znaczenie - oraz dodatkowe, „poboczne” elementy semantyczne: 'opowieść o czymś (o jakimś zdarzeniu)', a także - 'samo zdarzenie, awantura, sprawa', które pojawiają się w całym badanym okresie - z wyjątkiem lat 60., 70. XX wieku. Kolejne "poboczne" elementy semantyczne - 'nauka historii, nauczanie historii' uaktywnia się tylko w latach 30., 40., 50. 60. XX wieku, natomiast niuans znaczeniowy: 'historia jako nauka' - jedynie $\mathrm{w}$ latach 60., 70., 90. XX wieku oraz $\mathrm{w}$ pierwszym dziesięcioleciu XXI wieku. 
Podobnie rzecz się ma w wypadku leksemu społeczeństwo - tj. w całym badanym okresie w dyskursie parlamentarnym "aktywne” było znaczenie główne, podstawowe. Jednakże widać dobrze, jak w latach 30., 50., 60. XX wieku zanikało (przestało się uaktywniać) znaczenie 'wspólnota' w tym leksemie, a wyraźnie - obok podstawowego - ujawniało się znaczenie 'grupa środowiskowa, zawodowa' (co mogło wynikać z upowszechnienia się w tym czasie pojęcia "filozoficznego" czy politycznego: klasa społeczna). Następnie - w latach 70., 80. XX wieku - stało się odwrotnie, tzn. powróciło znaczenie 'wspólnota' (które w latach 90. XX wieku, a także $\mathrm{w}$ pierwszym i w drugim dziesięcioleciu XXI wieku znacząco nasiliło swoją aktywność), a zanikało (przestało się uaktywniać) znaczenie 'grupa środowiskowa, zawodowa' (chociaż i to znaczenie w latach 90. XX wieku, a także w pierwszym i w drugim dziesięcioleciu XXI wieku powraca - z nieco odmiennym niuansem semantycznym: 'grupa społeczna').

Na podstawie tych analiz można zatem zwizualizować fluktuacje zachodzące w strukturze semantycznej wyrazów używanych w polskim dyskursie parlamentarnym (na tle polszczyzny ogólnej); tu przeprowadzono takie pilotażowe badania $\mathrm{w}$ tym zakresie na przykładzie dwóch istotnych pojęć wyrażanych leksemami (a wyrazami w tekstach): historia oraz społeczeństwo. Okazało się, że oba analizowane tu pojęcia mają $\mathrm{w}$ polskim dyskursie parlamentarnym - w planie semantycznym, mówiąc nieco metaforycznie - swój główny nurt znaczeniowy, wokół którego grupują się niekiedy nurty poboczne. Natomiast w planie frekwencyjnym także widać wyraźnie utrzymywanie się pewnego stałego zainteresowania tymi pojęciami, tj. pewnej, stabilnej, średniej czy wysokiej frekwencji, która w obu wypadkach analizowanych tu leksemów wzrasta gwałtownie na przełomie XX i XXI wieku, co nie pozostaje bez korelacji z wydarzeniami z płaszczyzny pozajęzykowej: społeczno-polityczno-ekonomicznej w Polsce i w Europie Środkowo-Wschodniej. Analizy i spostrzeżenia powyższe pokazują - mam nadzieję, że przekonująco - jak nierozpoznanym jeszcze obszarem badawczym pozostaje polski dyskurs parlamentarny.

\section{WYKAZ SKRÓTÓW}

KORPUSOMAT - http://korpusomat.pl/ (dostęp: 5.10.2020).

CLARIN-PL - http://clarin-pl.eu/pl/strona-glowna (dostęp: 5.10.2020).

Korpus dyskursu parlamentarnego - http://clip.ipipan.waw.pl/PSC, http://sejm. nlp.ipipan.waw.pl/query_corpus/ (dostęp: 5.10.2020). 
SJPD - Stownik języka polskiego, 1958-1969, t. I-XI, red. W. Doroszewski, Warszawa: Państwowe Wydawnictwo Naukowe.

WSJP - Wielki słownik języka polskiego, red. P. Żmigrodzki, http://www.wsjp.pl/ (dostęp: 5.10.2020).

\title{
BIBLIOGRAFIA
}

Bańko M., 2001, Z pogranicza leksykografii i językoznawstwa. Studia o słowniku jednojęzycznym, Warszawa: Uniwersytet Warszawski. Wydział Polonistyki.

Bartmiński J., 2006, Językowe podstawy obrazu świata, Lublin: Wydawnictwo Uniwersytetu Marii Curie-Skłodowskiej.

Kieraś W., Kobyliński Ł., Ogrodniczuk M., 2018, Korpusomat - a tool for creating searchable morphosyntactically tagged corpora, "Computational Methods in Science and Technology", nr 24(1), s. 21-27.

Miodunka W., 1989, Podstawy leksykologii i leksykografii, Warszawa: Państwowe Wydawnictwo Naukowe.

Ogrodniczuk M., 2012, The Polish Sejm Corpus, [w:] Proceedings of the Eighth International Conference on Language Resources and Evaluation, red. N. Calzolari i in., Istanbul: European Language Resources Association (ELRA), s. 2219-2223.

Ogrodniczuk M., 2018, Polish Parliamentary Corpus, [w:] Proceedings of the LREC 2018 Workshop ParlaCLARIN: Creating and Using ParliamentaryCorpora, red. D. Fišer, M. Eskevich, F. de Jong, Paris: European Language Resources Association (ELRA), s. 15-19.

Wielki słownik języka polskiego PAN. Geneza, koncepcja, zasady opracowania, 2018, red. P. Żmigrodzki i in., Kraków: Instytut Języka Polskiego PAN.

\section{ON THE CONCEPTS OF HISTORY (HISTORIA) AND SOCIETY (SPOŁECZEŃSTWO) IN THE POLISH PARLIAMENTARY DISCOURSE (BASED ON THE CORPUS OF PARLIAMENTARY TRANSCRIPTS FROM 1918-2018)}

\begin{abstract}
The work conducted for over ten months at IPI PAN has resulted in the creation of a working (and still further developed) corpus of the 20th-century Polish parliamentarisms. The corpus was created using parliamentary transcripts from the years 1918-2018 and as for now it contains nearly 200 million segments. On this basis, a preliminary analytical work on the language of the Polish parliamentarism of the twentieth century is being conducted. One of the first issues is the preliminary lexicographical and lexicological analysis of the assembled corpus. In order to show the extent of the corpus and its chronological complexity, a lexical and semantic analysis will be subjected to, for example, such
\end{abstract}


lexemes as historia (history) and społeczeństwo (society). The analysis of the usage of these items in the Polish parliamentary discourse has shown that they are high frequency words, and that their meanings are subject to "specific pressures of parliamentarism" and slightly differ (depending on a particular period in history) from the meanings traditionally assigned to them in Polish lexicography.

Key words: semantics, lexicography, words, lexical frequency, Korpusomat 